\title{
FROM THEOLOGY TO MYSTAGOGY. THE INTERIORISATION OF THE PROTESTANT TRADITION BY A WORLD CITIZEN: DAG HAMMARSKJÖLD
}

\author{
J. Huls ${ }^{1}$
}

\begin{abstract}
This essay presents as paradigm the reflection of Dag Hammarskjöld on the history of his belief. It investigates how his initial expression of theological concepts gradually became a mystagogical process, interiorising the religious traditions in which he has grown up.

\section{INTRODUCTION}

When sociologists and psychologists conceive a research on religious beliefs, most often they start to interrogate people about concepts corresponding to traditional creeds (Dekker, De Hart \& Peters 1997). Research in spirituality is less interested in answers to questions whether people consider themselves as "believers" and how they may formulate their religious ideas. Spirituality focuses on the spiritual journey of a person and how the encounter with the divine reality may provoke in them a process of transformation. Theological language may be used to express the process of becoming conscious of the divine human relationship. This essay will present as paradigm the reflection of Dag Hammarskjöld on the history of his belief. What started in him as the expression of theological concepts gradually became a mystagogical process, interiorising the religious traditions in which he grew up.
\end{abstract}

\section{PERSONAL PERSPECTIVE AND PERSPECTIVE FROM GOD}

Each person finds him/herself located in a field of tension between the personal life journey and the perspective of God in which this life takes place. We experience our lives as a "drama" with ourselves as

1 Dr. J. Huls, Research Fellow, Department of New Testament, Faculty of Theology, University of the Free State, Bloemfontein; and Titus Brandsma Institute, Nijmegen. 
protagonists. We look for the essential and we grieve over any limitation and alienation detrimental to our will to live. This quest demands much patience and discernment. Too easily we are inclined to confound side issues and circumstances with the essential. We deceive ourselves and pursue illusions. Nevertheless, we may also easily get ourselves talked or manipulated into essentials in which case we yield to social pressure or lapse into ideologies, clichés, customs or traditions. Therefore, for the sake of performance in our own life journey, we need both introspection and feedback as integral to the process of discernment (Waaijman 2002:483-514).

In order to accompany somebody in this quest for the essential, we have to focus all our attention on this person and show genuine interest. We have to take the personal "drama" seriously, but at the same time also guide such a person in not making too much of it. In this way the personal situation - which seems so significant, might be discovered as the Face of God. In the concrete situations and circumstances prevailing in our lives, we may discover who God really is (Waaijman 2002: 922-934). A mature spiritual life demands that we are no longer obsessed by the tragic nature of our vulnerability, but that we learn to listen to the voice of God resonating in each circumstance and encounter. In this way everything becomes meaningful and a token of the divine. Indeed, God has created us as human persons within this world, within a particular situation, with this body, this history, this psyche. Success and failure, suffering and happiness are all part of our reality. Usually we get caught up in the project of our own life, taking our ideal self as being reality. However, we are not the cause of ourselves. Life cannot be seized; it can only be received in "obedience" from the hand of the other.

\section{DAG HAMMARSKJÖLD'S JOURNEY}

In Dag Hammarskjöld's life (1905-1961), we become aware of how his personal life story in this process of discernment, retreats into the background. Markings (Hammarskjöld 1988) is not so much a diary in which the subject is the leading figure, but a book of thoughts wherein he reflects on the meaning of life surfacing in concrete circumstances. In a process of growing awareness, his life becomes transparent in God's light. It is apparent that he lives in the field of tension. On the one hand 
he strongly focuses on himself. On the other hand, he discovers that it is only when we become oblivious to ourselves that it becomes possible to act in a just and ethical way. In this process, silence becomes the space in which he discovers how his true life orientation is created and how he has to act.

We may also indicate, in the process of discernment, a transition from "I" to "we." My performance may be considered as "good" when the other comes to the fore. Granting implies creating space for the other. Continuously we are confronted with the critical question of whether we really have the other in mind. Or is the Christian ideal of charity merely a cover for a subtle egocentrism and an inclination to perfection? Do we use the other as object of our own goodness? What is our real motivation? The spiritual maturity originating from discernment gives us the sensation of coming to life in the self-forgetfulness of love. The authentic person is born in loving the other. But the other comes to the fore in the gaze of our eyes. In this way the other discovers that he/she is worthy to be seen.

In 1950 Dag Hammarskjöld formulated this openness to the other as follows:
Hunger is my native place in the land of the passions. Hunger for fellowship, hunger for righteousness - for a fellowship founded on righteousness, and a righteousness attained in fellowship.
Only life can satisfy the demands of life. And this hunger of mine can be satisfied for the simple reason that the nature of life is such that I can realise my individuality by becoming a bridge for others, a stone in the temple of righteousness.
Don't be afraid of yourself, live your individuality to the full - but for the good of others. Don't copy others in order to buy fellowship, or make convention your law instead of living the righteousness.
To become free and responsible. For this alone was man created, and he who fails to take the Way which could have been his shall be lost eternally (cf. 1988:62.)

Our desire for justice is only satisfied if we are inspired to grant others life. This happens if we are not so much consumed by the self that we begrudge the other his/her life. We are only in the centre of our own being when our essence bridges the gap to the other. When the other may exist in his/her own right, resisting our dominance, the door of heaven opens up. Spiritual maturity does not mean that we have 
to deny our own nature. Our characteristic features are the space where God may work. In this respect, concessions are forbidden. We should not hide our own nature. Sacrificing the authentic being, translates to nothing less than a kind of bribe to buy the attention of others. Our vocation is to live up to the prophecy of justice. This is a heavy responsibility.

This journey to spiritual maturity is the reflection of a personal experience. He (Hammarsskjöld) has gradually grown into an openness towards the other. Markings depicts the struggle which leads to selftranscendence and self-forgetfulness. In this way he has discovered what the word "love" means. It is a stretching towards the other which surpasses our autonomy. This is the mystical space which enables us to receive ourselves from the hands of the other in complete surrender. Hammarskjöld understood his election as Secretary General of the United Nations in 1953 as the implementation of his mystical call (Hammarskjöld 1988:88). ${ }^{2}$

\subsection{Reflecting on an existing creed}

In 1954 Hammarsskjöld gave a talk on the Canadian radio in a programme called This I believe (cf. Foote 1962a:23-24; Foote 1962b:2425). In this programme important persons were invited to speak about their personal philosophy or beliefs. The title of this particular broadcast was Old creeds in a new world. The word "creed" in this title does not have the limited meaning of a profession of faith for Hammarskjöld, as is the case in Christian Churches. According to him, each human person has a creed because his/her life receives an inner orientation from principles and ideals. This creed may have — as in the past - the meaning of a confession, but currently it often has a less explicit religious meaning. Hammarskjöld was asking himself whether the principles and ideals expressed in the creeds of former generations could still be used in the modern world, or whether the current world had changed so much that they had lost their traditional meaning.

2 Hammarskjöld is citing, on April 7, 1953, Thomas a Kempis, Imitation of Christ II, 10: Their lives grounded in and sustained by God, they are incapable of any kind of pride; because they give back to God all the benefits He has bestowed on them, they do not glorify each other, but do all things to the Glory of God alone. 
The title expresses Hammarskjöld's attitude towards life. In fact, he shared the hesitation of many of his contemporaries who experienced the Second World War. He sensed that he was living in a new world that still had to find answers to completely new problems. It was evident that rapid technological development had its dark side too. A conflict which in the past was solved at local level could result in a worldwide catastrophe. For Hammarskjöld it was evidently a question of a new world with new problems asking for new solutions.

At the beginning of this radio talk he notes, The world in which I grew up was dominated by principles and ideals
of a time far from ours and, as it may seem, far removed from the pro-
blems facing a man of the middle of the twentieth century. How-
ever, my way has not meant a departure from those ideals. On the
contrary, I have been led to an understanding of their validity also
for our world of today. Thus, a never abandoned effort frankly and
squarely to build up a personal belief in the light of experience and
honest thinking has led me in a circle; I now recognize and endorse,
unreservedly, those very beliefs which were once handed down to me.

As is usual in the years of our childhood, we are educated with values, principles, ideas and creeds of our parents and other important people. In the beginning they are foreign to us. We accept them because we identify ourselves with them or because they belong to the conventions of the time. However, this does not mean that they really belong to our inner world. A long process of interiorisation is necessary if principles and ideals are to become part of our personal life. Indeed, a grammar of inner life does not exist. Things which are acquired may become interiorised by way of experience in daily life. It is this experience that confronts us with the value to be attributed to principles, ideals and creeds.

As is clear from his writings, Hammarskjöld experienced the difficulty of connecting the principles and ideals of his youth to the problems confronting him as a person halfway through the twentieth century. As secretary of the United Nations, the principal problem confronting him was that of maintaining world peace. The new equilibrium in the world demanded multilateral diplomacy. Representatives of the various countries could not just simply defend their own interests, but were also required to accept responsibility for world events. Each local conflict carried with it the potential of becoming a world 
conflict - especially in the days of nuclear armament and the cold war. Therefore it is understandable that he should be asking himself whether the creeds from a remote past could offer solutions to the current situations. Conflict could no longer be fought on local level and not have any consequences further afield. If old patterns could no longer function in the new world, what then about our philosophy of life? Nevertheless, he writes that these traditional principles and ideals have become personal beliefs and inner convictions in the light of his experience and honest reflection.

Belief - whether it is the belief in God or the belief in the value and dignity of the human person - does not come out of the blue. As a language, belief has to be learned. However this is not sufficient. We may be informed about a belief, be intrigued by it, or even analyse it in academic fashion, but this is different to being convinced deep down that these traditional principles and ideals form the basis of our lives. How we arrive at this answer can only be learned through the experience of life itself. Nobody is able to show us the road to spiritual maturity. Study and personal effort can bring us to the border of that area where only silence dwells, because there nothing can be said any more. What remains is just a matter between the human person and him/herself or God. According to Hammarskjöld, the consequences of this inner dialogue are evident to everybody. Persons who are reconciled with themselves are independent, courageous and honest in their relationship with others. They know that only their own integrity is the criterion of their activity (cf. Foote 1962a:80-85). ${ }^{3}$

3 Cf. Dag Hammarskjöld, International service, Address at Johns Hopkins University Commencement Exercises, Baltimore, Maryland, 14 June 1955 (In Foote 1962a: 80-85):

But from what he [i.e. Russell W. Davenport in The dignity of man, Harper \& Bros. 1955] had already written, it is apparent what he wanted to say: that the dignity of man, as a justification for our faith in freedom, can be part of our living creed only if we revert to a view of life where maturity of mind counts for more than outward success and where happiness is no longer to be measured in quantitative terms. I doubt whether the author, had he been given the chance to complete his work, would ever have found it possible to go far beyond this point, because the final reply is not one that can be given in writing, but only in terms of life. There is no formula to teach us how to arrive at maturity and there is no grammar for the language of inner life. His study, 


\subsection{Traditions represented by his father}

The next section of Dag Hammarskjöld's radio talk works out the different principles and ideals which he received in his youth and which gradually became part of his conviction, since they express his own inner life. First he focuses on the tradition represented by his father:

From generations and soldiers and government officials on my father's side I inherited a belief that no life was more satisfactory than one of selfless service to your country — or humanity. This service required a sacrifice of all personal interests, but likewise the courage to stand up unflinchingly for your convictions.

Although Hammarskjöld did not know his father very well, this radio talk and also some of his other speeches resound with a tone of deep respect for a man who remained until the end of his life, faithful to his inner convictions. The violence of the First World War did not prevent him from remaining true to the principles of international law. Neutral states like Sweden had, according to him, a special obligation towards the future.

Hammarskjöld certainly shared his father's belief in international law. However, in his Canadian radio talk he does not refer to the concrete ideals of his father, but to the attitude behind these convictions. Hjalmar Hammarskjöld and many other members of the family consecrated themselves to the service of the state. They were convinced that "no life was more satisfactory than one of selfless service to your country — or humanity." This service does not always result in applause — as became painfully clear to Hammarskjöld when he was still young (Foote 1962a:78-79; Foote 1962b:87-88):

In looking back to find a situation reflecting the essential core of Hjalmar Hammarskjöld's personality, I pause before this recollection.

It is late in the day, the third day of the defense debate of 1925. In the First Chamber, the discussion has largely been colored by echoes from the great battles of 1914. Hjalmar Hammarskjöld, who has sharply fought for his views from his position outside the parties, has be-

like the effort of every single individual, finally led him to the doorstep where the rest is silence because the rest is something that has to be resolved between a man and himself. The rest is silence - but the results of the inner dialogue are evident to all, evident as independence, courage and fairness in dealing with others evident in true international service. 
come a personal target. In this situation he takes the floor for the last time. He ends with these words: "It was said here before the recess that large circles realized that in the question of defense they could follow no poorer counselor than I. To the extent that this is true, I would ask you gentlemen all to forget, and forget completely, that I am a friend of strong defenses, so as to prevent this from being an obstacle to a good decision. Who takes the initiative, who exerts influence, is so utterly indifferent compared to the one great question: to make our country secure for the future.

To the nine-year-old listener in the gallery, these words epitomised a life of faith in justice and of self-effacing service under a responsibility which unites us all.

His father's answer impressed the nine year old Hammarskjöld, who sensed the unselfish attitude of his father. Despite the rhetoric drama of his speech, he knew that the national interest was more important to Hjalmar Hammarskjöld than his own role in this case. When his person became a hindrance to a right decision, he was disposed to sacrifice his own position. This awareness that our service to others may involve at the end a sacrifice of all personal interest, characterised, according to Hammarskjöld, the spiritual maturity of his father. Faithful to his own convictions, he knew that there was only one solution to bringing the case he defended to a happy conclusion. His unselfishness was therefore not a sign of weakness, but of inner strength. Hjalmar Hammarskjöld could give up his position precisely because he had the inner certainty that he had acted in the best way.

Other speeches by Dag Hammarskjöld (cf. Foote 1962a \& 1962b) also make clear that unselfish service does not mean that a servant has to set himself aside. To the contrary, service demands in the first place that we be ourselves. It is not a flexibility and adaptation to the demands of others, but an inner strength enabling one to live in correspondence with one's own ideals and convictions. However, this is not a form of self-interest, but of honesty enabling us to open our heart and spirit to every circumstance in which we find ourselves. The greatest contribution to others is not an attitude of taking care of others and trying to comfort them, but of faithfulness to ourselves and an openness resulting from spiritual maturity. This mature service is expressed in the absence of fear and the awareness that the fate of the person is the consequence of his own action. In this way there is no longer a question 
of desperate attempts to be more and different than the person he/she really is. Service means dedication to the other on the basis of independence and liberty, because only these attitudes enable us to encounter the other.

\subsection{Traditions represented by his mother}

After focusing on the tradition of his father, Dag Hammarskjöld focuses on the spiritual tradition of his mother:

From scholars and clergymen on my mother's side I inherited a belief that, in the very radical sense of the Gospels, all men were equal as children of God, and should be met and treated by us as our masters in God.

The relationship with his mother, Agnes Almquist, was rather intense. It is therefore not surprising that she especially represents the way he believes. It is striking how God and the experience of God are intrinsically interwoven with the encounter and association with people. The fundamental orientation of the human person has two aspects: on the one hand all humans are equal as children of God, and on the other, they have to be treated as our masters in God.

That human persons are equal as children of God, does not mean that Hammarskjöld holds the bourgeois ideal of equality as in the French revolution. Human persons are equal to each other because they are children of God, or because they have their origin in God. This idea may not be understood as a theological concept, but as the expression of experience. The fundamental equality of the human person may be experienced by us when we are aware that we are not at the origin of life, but receive life as an undeserved gift. We may live Life (with a capital 'L'), but never possess it. On one occasion Hammarskjöld expressed this experience in Markings (1988:75) as follows:

It occurs to you in a flash: I might just as well never have existed. Other people, however, seeing you with a guaranteed salary, a bank account and a brief-case under your arm, assume that you take your existence for granted. What you are can be of interest to them, not that you are. Your pension — not your death — is what you should think about "while the day lasts".

The fact that life in itself is divine - this means with our life we live out of God - makes us thoroughly equal in receiving life. This 
does not mean that we are equal in the way we spend our days or in the positions we hold. As many variations exist in a human being as creature of God as there is infinity in God. This takes nothing away from the human person, but indicates precisely the fundament of human dignity. In each human person we may discover the Face of God if we dare to consider ourselves purely as a gift of God. The experience that we, just like every other human person, exist out of the divine source of life, makes Hammarskjöld say:

All men were equals as children of God, and should be met and treated by us as our masters in God.

In fact, he does not say that the other person is our master. If that would be the case, we would be completely at the mercy of the other. It is a matter of an experience comparable to disinterested service. According to Hammarskjöld, service may only be disinterested, when it is experienced through an inner centre. Others are our masters because this more substantial level really opens us to the other and makes us see the other from the perspective of God. When we really listen to the other on the level of our existence in God and are obedient to this experience, the other person becomes a master in God. It is of no consequence that this substantial level might be invisible to the other person, because we are requested to remain faithful to this "truth" of the other person.

\subsection{Interiorisation of ideals}

After mentioning the convictions of his father and mother, Hammarskjöld elaborates on the process of interiorisation of these ideals:

Faith is a state of the mind and the soul. In this sense we can understand the words of the Spanish mystic, St. John of the Cross: "Faith is the union of God with the soul." The language of religion is a set of formulas which register a basic spiritual experience. It must not be regarded as describing, in terms to be defined by philosophy, the reality which is accessible to our senses and which we can analyze with the tools of logic. I was late in understanding what this meant. When I finally reached that point, the beliefs in which I was once brought up and which, in fact, had given my life direction even while my intellect still challenged their validity were recognized by me as mine in their own right and by my free choice. I feel that I can endorse those convictions without any compromise with the demands of that intellectual honesty which is the very key to maturity of mind. 
In this section the word "faith" and the deep-rooted experiential meaning of the word, play an essential role (cf. Huls 1991:623-656). The language of religion should be understood on this substantial level. The expression of faith does not speak about something that is perceptible as an object of reality, but refers to the "unheard-of reality" (in the literal sense of what cannot be heard in reality). It is to this experience that the language of faith is referring, conducting and seducing us. The sensitivity of the "secret" of reality or the "miracle" of the other person causes this to frequently surface through the images. However, the other person remains at the same time intangible. This experience evokes in us a love which surpasses ourselves and goes beyond our logic. This love affects us, but remains in itself intangible. This "blow" through which the Life self forcefully enters our lives, is expressed by Hammarskjöld in the words of John of the Cross: "The union of God with the soul".

In this way we realise that real life only occurs on the other side of the border. Quoting John of the Cross, Hammarskjöld makes it clear that faith refers to an attitude in which not our own person or our own will is at the centre, but the relation with that layer where we realise that it is God guiding and moving us and creating us all the time. Life in which we accept the guidance of that which is outside and beyond us - although in us - is the beginning of our religious or spiritual journey. In contrast with our normal habit of reaching for a precise goal, this way can only be travelled with a questioning attitude. We are not in command of this journey. We are only able to be guided by our sensitivity to the mystery of life. This mystery remains beyond our concept and the mystics call it "love." In fact, love is at odds with our survival instinct and our aspirations to happiness. Nevertheless, the person who lives on this substantial level is aware of being intensely loved.

These moments are so fundamental to the human person, that it not only remains in our memory throughout our entire lives, but it also determines and orientates our activity and our relationship with others. For Dag Hammarskjöld this meant that the "beliefs" which he received from his parents, became intrinsically elucidated by personal experience. Therefore he does not speak about ethical obligations or ideals, but about "beliefs." The disinterested service of his father originates from the same source as the basic orientation towards the other of his mother. 
Both these religious attitudes originate from the full awareness that the vocation of the human person does not consist in self-protection, but in the love which God awakens in us. This love carries us along a way which may seem illogic from our human perspective, but which has its own particular logic. In fact, in this way we may live according to our deepest essence if we remain honest towards ourselves.

\subsection{Schweitzer as guide}

In his quest for a personal synthesis, Dag Hammarskjöld discovered Albert Schweitzer as an excellent guide from the Protestant tradition:

The two ideals which dominated my childhood world met me fully harmonized and adjusted to the demands of our world of today in the ethics of Albert Schweitzer, where the ideal of service is supported by and supports the basic attitude to man set forth in the Gospels. In his work I also found a key for modern man to the world of the Gospels.

The two ideals which predominated in the youth of Hammarskjöld were rediscovered in the ethics of Albert Schweitzer. The fact that they were adjusted to the conditions of our time enabled him to arrive at a personal integration. On the one hand, service is the condition for the basic orientation to the other, as claimed in the Gospels. On the other hand, service may only develop into real service when it is fostered by a basic orientation to the other. This means that service always has to be linked to a listening attitude on the substantial level of the desires of God. Only when the other in this way is listened to and obeyed, may a willingness to help become a real service to the other. Indeed, service is basically a contemplative attitude and demands in the listener, deep down, an openness to listen to God. In this way it becomes possible to really listen to the other, without presenting in advance solutions to their problems, because we think that the persons are either "poor" or "pitiful." In fact, he/she may be asking for our help for completely different reasons. Real service demands that we be honest with ourselves with regard to the question "Do we help the other for the sake of ourselves in order to win his/her sympathy — or are we really involved in helping the other?" This view regarding service is the key to understanding the gospel for Hammarskjöld. In Scripture we see how Christ was completely at the service of his fellow men, on the level of their substantial needs. This attitude originates from the source of divine life, which he called his father. 


\subsection{Mystical traditions}

In Markings we see clearly how the spiritual journey of Hammarskjöld was connected to the mystical traditions:

But the explanation of how man should live a life of active social service in full harmony with himself as a member of the community of the spirit, I found in the writings of those great medieval mystics for whom "self-surrender" had been the way to self-realization, and who in "singleness of mind" and "inwardness" had found strength to say yes also to every fate life had in store for them when they followed the call of duty, as they understood it. Love - that much misused and misinterpreted word - for them meant simply an overflowing of the strength with which they felt themselves filled when living in true self-oblivion. And this love found natural expressions in an unhesitant fulfillment of duty and in an unreserved acceptance of life, whatever it brought them personally of toil, suffering — or happiness.

I know that their discoveries about the laws of inner life and of action have not lost their significance.

In contrast with the usual esoteric ideas of mysticism, Hammarskjöld considers mysticism as belonging to the area of charity or social service. The encounter full of adventure of the mystics with divine love is according to him not indulgence in navel-gazing but an orientation to the inner-world in union with external activities. In this way we do not become unilateral in our concentration on God, but arrive at a holistic unity of the different levels of human life. Therefore mysticism is not contrary to political activity, but much rather interwoven with it. Hammarskjöld understands that the love of God is unconditional, and therefore an undeserved gift which occurs in our lives. By way of this inner orientation, we arrive at a "singleness of mind" because we get rid of the ambivalence of self-interest and self-concern. Transformed into this simplicity (cf. Huls \& Blommestijn 1995) - this means the complete unselfishness of divine love — we abandon ourselves unconditionally to be carried along by the strength of love. In this way we cannot accede to the other out of ourselves, but we are carried along by the love of God to meet the appeal which the real needs of the other present to us. The service to the other in this way becomes a mystical experience. We love the other with the love of God. We envision the other with the eyes of God. We think about the other with the thoughts of God. As mystics we do not withdraw ourselves from society, but act on the call of our sense of duty. In this way we say "yes" 
to everything that the concrete life has in store for us. On the basis of the Face of God, we discover the real countenance of the other.

For Hammarskjöld, love is not an emotion. It is simply the overflow of the strength of God's love. We do not cling to it. In true selfforgetfulness we move away from ourselves and towards the other. We are not at the centre of our own affection, but the other, whom we contemplate through the eyes of God, is. In this, the centre of attention is shifted from ourselves to the other. It does not happen in our own strength, but because we have been overcome by the strength of God's love. On the basis of the unconditional love of God, we arrive at an unconditional devotion to duty or unconditional service. Our commitment is not proportioned to ourselves and our self-interest but to the face of the other who calls us. Therefore, love is not a romantic experience but the absolute acceptance of life which enables us to meet the other without reservations, whatever it might involve: tensions, suffering or happiness. Hammarskjöld understood very well that real service or authentic love is the road which may only be travelled in faith. Faith means an orientation to our inmost self and at the same time the substantial attitude of our orientation towards the other. At that moment when our lives really have its origin in God, these two attitudes are just one. 


\section{BIBLIOGRAPHY}

\section{DAVENPORT R W}

1955. The dignity of man. New York.

\section{Dekker G, De Hart J \& Peters J}

1997. God in Nederland: een statistisch onderzoek naar godsdienst en kerkelijkheid in Nederland. Amsterdam.

FoOTE W (ED.)

1962a. Dag Hammarskjöld speeches. A selection. Stockholm.

1962b. Dag Hammarskjöld, Tal 1953-61. Stockholm.

\section{HAMMARSKJÖLD D}

1988. Markings. London.

\section{HuLs J}

1991. Dag Hammarskjöld als Interpret des hl. Johannes vom Kreuz. In: O. Steggink (ed.), Juan de la Cruz, Espiritu de Llama. Estudios con ocasión del cuarto centenario de su muerte (1591-1991) (Roma/Kampen), pp. 623-656.

\section{Huls J \& Blommestijn H}

1995. The simplicity of love as the key: Bishop Zwijsen's special emphasis. An inquiry into the religious life (transl. John Vriend). 's-Hertogenbosch-Tilburg.

\section{ThOMAs A Kempis}

1955. The imitation of Christ. New York.

\section{WAAIJMAN K}

2002. Spirituality. Forms, foundations, methods. Louvain.
Keywords
Dag Hammarskjöld
Spirituality
Mystagogy
Protestantism

\author{
Trefwoorde \\ Dag Hammarskjöld \\ Spiritualiteit \\ Mistagogie \\ Protestantisme
}

